\title{
A Study of Nigerian Youths' Understanding, Perception of HIV/AIDS Phenomenon and Sex Attitudes: The Link between Acceptance of Reality and Marketing Motives of Multinational Pharmaceutical Companies
}

\author{
Mufutau Akanbi Awoniyi \\ Department of Marketing, Faculty of Management Sciences, Lagos State University, \\ Ojo, Nigeria \\ Email: mugafric2001@yahoo.com
}

Received 20 February 2015; accepted 24 July 2015; published 27 July 2015

Copyright (C) 2015 by author and Scientific Research Publishing Inc.

This work is licensed under the Creative Commons Attribution International License (CC BY). http://creativecommons.org/licenses/by/4.0/

(c) (i) Open Access

\section{Abstract}

The HIV/AIDS Pandemic is one of the most serious and urgent public health challenges facing the government people and civil society in Nigeria today. The spread of the HIV responsible for AIDS has actually come under great control and management in many western countries. The developing countries such as Nigeria are still very much confused and battling with the reality and acceptance of the deadly virus in the society. In Nigeria, traditional beliefs, religion, cultural influences, poverty and social vices have hindered most of the genuine efforts of government and non governmental agencies to tackle HIV/AIDS menace in the country. Most of the youths in Nigeria, especially the secondary school, college and undergraduate students are very much aware that the sexual intercourse is the most prevalent mode of HIV/AIDS transmission in the country. Yet, for a variety of reasons, many of the youths in Nigeria continue to engage in sexual behaviours which are unsafe and could put them at risk of HIV/AIDS infection. The study discovers among others that some people mostly youths in Nigeria see HIV/AIDS as development propaganda to help multinational pharmaceutical companies sell and market their drugs and other sex related products in the country. It is also concluded that the information on HIV/AIDS and the sexual behaviour and the practice among Nigerian youths is still very much inadequate.

\section{Keywords}

HIV/AIDS, Sex Attitudes, Nigerian Youths, Marketing Concept, Rapes, Students/Promiscuity 


\section{Introduction}

Apart from the recent Ebola virus, no single phenomenon has changed the face of sexual relationship as much as the issue of the virus known as HIV or the Human Immunodeficiency Virus. It is the virus that causes AIDS which stands for Acquired Immune Deficiency Syndrome. When a person is infected with the virus, the body fluid such as blood, semen and reproductive organs will contain HIV/AIDS and antibodies against the virus. The virus stays in the body and slowly destroys the body defence mechanisms. The body's natural defence system is weakened and the infected person becomes vulnerable and is at the mercy of all kind of infections such as prolonged neck, persistent cough, skin infection and unexplained weight loss [1].

As reported by Strong Devault, Sayad, B.W. and Yarber, W.L., [2] the HIV was discovered in 1980's. The mode of transmission of HIV differs throughout the world, but sexual intercourse is reported to be the most prominent mode of transmission in sub-Saharan Africa. It accounts for about $90 \%$ of all infections [3]. Young people are particularly vulnerable to HIV infection because of the physical, psychological, social and economic attributes of adolescence [4]. Again, the young people are at risk due to high level of sexual behaviours and attitudes. The abstinence and the use of condoms have been recommended as measures for controlling the spread of HIV/AIDS among people in Nigeria, but the strategy of prevention remains very low.

\section{Background of the Study}

According to report, Nigeria is no. 17 among the countries with the highest level of HIV infection in the world (Table 1). Benne top the list of highest HIV/AIDS infected state in Nigeria (Figure 1). Abunku [5] disclosed that over 600,000 persons are currently living with the dreaded HIV/AIDS in the state.

The Nigerian Watch [6] reported that over 1 million people in Benne State representing nearly one quarter of its population are currently living with HIV. Traditionally, Benne State has a high proportion of Nigerian soldiers. This then may explain the development as men of the Nigerian Army have been known to contact and spread the disease while on international peace-keeping assignments [6]. Again, Ekweremadu [7] reported that 8 out of 10 Nigerian men do not use condoms during sexual intercourse.

According to Wende [8], the Executive Secretary of the Benue State action on Controls of AIDS, 400,000 children living with the virus have been placed on antiretroviral drugs and that 708,600 adults are living with the virus. The statistics also confirmed that about two out of five people in Benue State are living with HIV [8].

In Nigeria today, many people are knowledgeable and have made to know much about HIV/AIDS through different information messages (words of mouth, radio, television, bill boards, prints and other electronic means) provided by government and non-governmental agencies. With all the efforts of government and others on HIV/AIDS awareness among the youths, the messages appear less effective [9].

The youths in Nigeria are yet to develop the attitudes and behaviours that would stop the deadly disease. A study by Odu and Akande [10] on extra-marital sex in Nigeria shows that about $72.2 \%$ of Nigerians have frequent sex. However, the threat of HIV/AIDS seems not to impact changes or fear in the conduct of their practice of safer sex. According to Davis and Weller [11] safer sex practices include knowing the sexual history of the sexual partner, reducing the number of sexual partner, agreeing not to share sex with any other partners for the duration of a specific relationship.

Premarital and extramarital sex continues to be on widespread and increase in every dimension. The youths in Nigeria regardless of HIV/AIDS threat are reported having broad sexual network, multiple concurrent sexual partners and unprotected sex [10]. It was also reported that some female University students in Nigeria even solicit and advertise for sex by posing nude on the internet [12].

Many of the youths in Nigeria have different opinion and misinformation as to the HIV/AIDS phenomenon being used by western countries as propaganda to reduce population in Africa, put the continent in its right place and make money from the region. Others group of people belief that HIV/AIDS is as result of God's anger or the work of witchcraft. While another have the belief that some multinational pharmaceutical companies introduced the virus into human system to make money from their "New products" development strategy.

As a result of this, many of the Nigerian youths do not maintain sexual exclusivity. Some of the youths in Nigeria that belief in the use of conditions as a very effective technique for HIV/AIDS prevention rarely use them. In Nigeria, traditional beliefs, religion, cultural influences, poverty and other practices have hindered must of the genuine efforts of government and non governmental agencies to tackle HIV/AIDS menace. 
Table 1. Countries with the highest level of HIV infection.

\begin{tabular}{|c|c|c|}
\hline$\Delta$ & Country & Adult prevalence rate (\%) \\
\hline 1. & Swaziland & 25.90 \\
\hline 2. & Botswana & 24.80 \\
\hline 3. & Lesotho & 23.60 \\
\hline 4. & South Africa & 17.80 \\
\hline 5. & Zimbabwe & 14.30 \\
\hline 6. & Zambia & 13.50 \\
\hline 7. & Namibia & 13.10 \\
\hline 8. & Mozambique & 11.50 \\
\hline 9. & Malawi & 11.00 \\
\hline 10. & Uganda & 6.50 \\
\hline 11. & Kenya & 6.30 \\
\hline 12. & Tanzania & 5.60 \\
\hline 13. & Cameroon & 5.30 \\
\hline 14. & Gabon & 5.20 \\
\hline 15. & Equatorial Guinea & 5.00 \\
\hline 16. & Central African Republic & 4.70 \\
\hline 17. & Nigeria & 3.60 \\
\hline 18. & Chad & 3.40 \\
\hline 19. & Congo, Republic of the & 3.40 \\
\hline 20. & Cote d'Ivoire & 3.40 \\
\hline 21. & Burundi & 3.30 \\
\hline 22. & Togo & 3.20 \\
\hline 23. & Bahamas, The & 3.10 \\
\hline 24. & Rwanda & 2.90 \\
\hline 25. & Djibouti & 2.50 \\
\hline 26. & Guinea-Bissau & 2.50 \\
\hline 27. & Belize & 2.30 \\
\hline 28. & Angola & 2.00 \\
\hline 29. & Gambia, The & 2.00 \\
\hline 30. & Haiti & 1.90 \\
\hline 31. & Ghana & 1.80 \\
\hline 32. & Jamaica & 1.70 \\
\hline 33. & Sierra Leone & 1.60 \\
\hline 34. & Liberia & 1.50 \\
\hline 35. & Trinidad and Tobago & 1.50 \\
\hline 36. & Barbados & 1.40 \\
\hline
\end{tabular}




\section{Continued}

\begin{tabular}{ccc}
\hline 37. & Guinea & 1.30 \\
38. & Thailand & 1.30 \\
39. & Benin & 1.20 \\
40. & Burkina Faso & 1.20 \\
41. & Estonia & 1.20 \\
42. & Guyana & 1.20 \\
43. & Sudan & 1.10 \\
44. & Ukraine & 1.10 \\
45. & Mali & 1.00 \\
46. & Mauritius & 1.00 \\
47. & Russia & 1.00 \\
48. & Suriname & 1.00 \\
49. & Dominican Republic & 0.90 \\
50. & Panama & 0.90 \\
$\nabla$ & &
\end{tabular}

Source: [16]

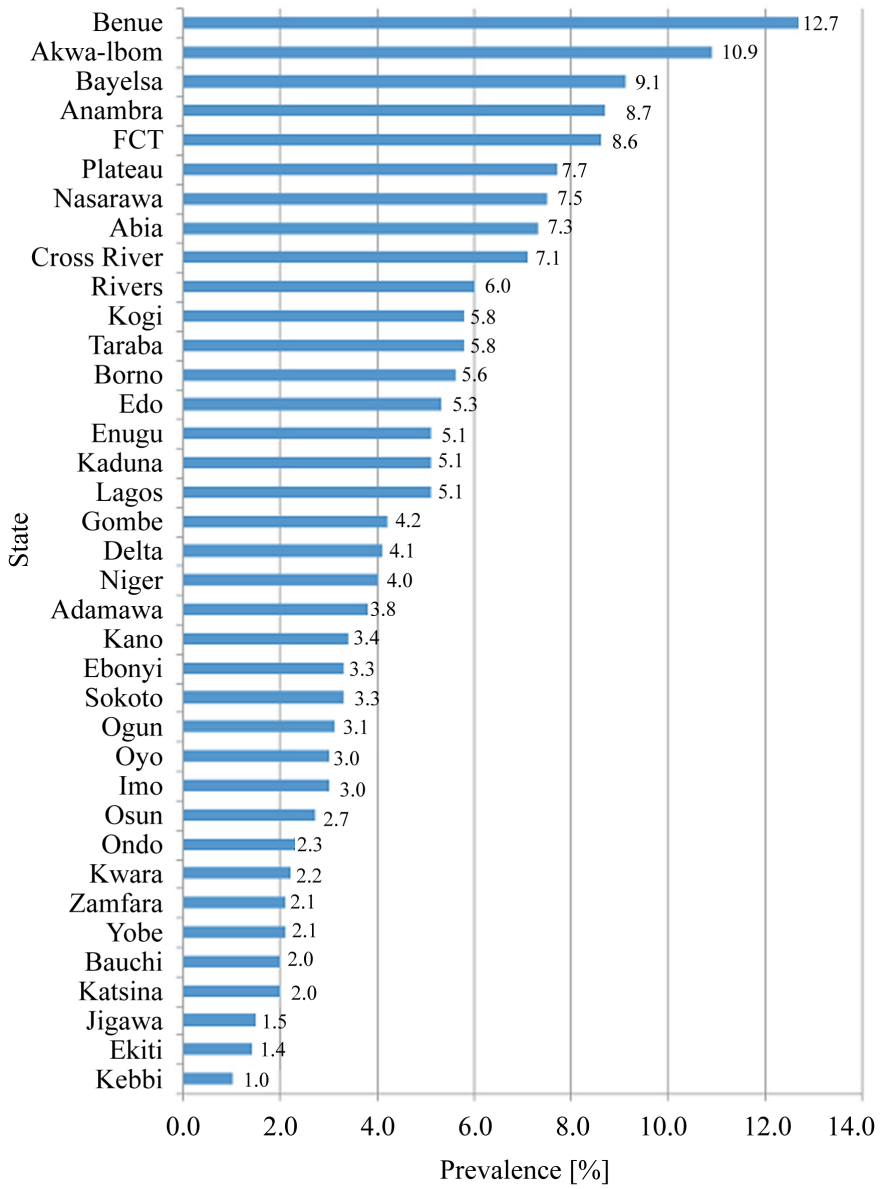

Figure 1. HIV/AIDS infected states in Nigeria. Source: [5]. 
The study shows that a great number of condom users among youths in Nigeria expressed misgiving ranging from its restriction of natural sex pleasure and enjoyment, low and poor quality of some of the condoms that breaks and burst during intercourse, among others. Despite the fact that many of the condoms and other contraceptives are cheaper in the country, those that use them are not consistent in their behaviours [12].

From several research studies, there is no doubt that the youth in Nigeria have been well sensitized about HIV/AIDS, its potent dangers and various preventive measures. Yet, a survey and report from most of the medical centres, hospital and clinics around the country shows that a great percentage of HIV/AIDS victims are youth. It is envisaged that there are other salient factors responsible for youth's carelessness and lackadaisical attitudes toward this deadly pandemic which need urgent attention in the country. Therefore, there is need to investigate the Nigerian youths understanding, perception of HIV/AIDS phenomenon, prevention and their sex attitudes with a view to examine the marketing motives of some pharmaceutical companies on sexually related products. From the foregoing, the study specifically aimed at discovering the perception of HIV/AIDS among University and Polytechnic students in Nigeria. The objectives of the study include: determining the knowledge, attitudes and sex behaviour and practices relating to HIV/AIDS among youths in Nigeria; examining if behavioural change program by government and non governmental agencies can help prevent and reduce HIV/AIDS infection; determine whether sex education can help create objective attitudes toward sex among youths in Nigeria.

In this study, the following general questions were raised: what percentage of Nigerian youths (college students, undergraduates, etc.) use condoms during sexual relationships? Are Nigerian youths aware of some of the guidelines for safe sex practices? And why are some youths in Nigeria not using condoms and other contraceptives in spite of knowledge and preventive methods against HIV/AIDS? The hypotheses tested were to see: if there is no significant relationship between knowledge of safer sex practice and the use of condoms in sexual relationship; if there is no significant relationship between the knowledge of condoms use as effective method for HIV/AIDS prevention.

\section{Sex Services and Prostitutions Business in Nigeria}

All over the country there are towns and cities where prostitution are very dominant among girls and women. From Lagos to Abuja, Port Harcourt to Maiduguri and Ibadan to Sokoto towns and cities of prostitutes are very common in Nigeria. There are also road sides prostitute where students, young married women, divorces, widows and single mothers openly solicit for patronage from passers-by. These young girls and women in various sizes, shapes, color and tribes would line up the streets to display their various brands and products attraction such as heavy buttons, big apple size breast, skimpy attires, and sappy pants etc. Going round the towns and cities of prostitutes in Nigeria witness very young girls of between 14 to 15 years and other that are not so young [13]. The rise in prostitution among girls in Nigeria is as a result of deep poverty in the country [13].

Some of the notorious towns and cities of prostitutes in Nigeria are: FESTAC town, Allen Avenue, Ikeja in Lagos State; Port Harcourt; Abuja; Kano; Kaduna; among others. The street prostitutes in Nigeria usually do not have any fixed rates for sex service charges according to the survey. The market rate for sex depend on the class and grade of the lady, the time of the month, seasons and desperations of the call girl to get something for the night or day. Usually, the street prostitutes charge between $\$ 1500$ to $\$ 2500$ and all night outing or contract attract between $\$ 3000$ to $\$ 10,000$ depending on power of negotiation between the parties [13].

\section{Contraception and Traditional Belief among Some People of Nigeria}

Makoko is a densely populated community area in Lagos State. It is a water side rural area and populated mostly by the Egun tribe who are fishermen. The Egun men who according to report are in this community do not use or like to use condoms due to their long held traditional belief in the old practice of coitus interrupts, also known as the withdrawal or pull-out method during sexual intercourse. For ages, the pull-out method has been used as an effective birth control worldwide and the Egun men have been adopting this system. According to report, some of the reasons Egun men do not use condoms are: the chemical and odour from condoms; the fear that chemical used in preserving the condoms could cause problems and may be harmful to the penis; that the use of condoms could bring diseases on its own as the sperm ejected into the condom sometimes goes back into the penis or manhood. Some of the diseases the Egun men belief condoms use can cause is known as "Foon". And Foon is a disease that may makes urination by men to be very difficult [14]. 


\section{HIV/AIDS Pandemic}

The HIV/AIDS pandemic is one for the most urgent and important public health challenges facing governments and civil societies all around the world today. Aids has gone a long way since it was discovered among gays 1981 and reached endemic level in the USA and still remain pandemic in Africa, Asia and Latin America [15]. In 1999 the estimated number of people living with AIDS was 36.1 million and 25.3 million was from Sub- Sahara Africa [15]. UNFPA estimated that HIV positive people worldwide increased to 38.6 million as at end of 2005 with an estimated 4.1 million new infections [15].

In Nigeria, current population of HIV positive people is put at 3.1 million according to the Punch, 13th March, 2013. Africa including Nigeria still remains the epicentre of the pandemic with South Africa topping the most infected nations-with an estimated 18.1\% infection rate among youths and adults between 15 - 49 years [15].

According to UNAIDS, it is estimated that $80 \%$ of all new HIV/AIDS infections are among young people (about 7000 young people become infected everyday) and 30\% of 40 million people living with the disease in the world are between 15 - 24 years of age and $50 \%$ of them are female. Worldwide adult HIV cases are split almost evenly between men and women [2]. According to Strong et al, the various population groups that are mostly affected are men who have sex injection drug users, etc. It was reported that HIV/AIDS always thrives in all-male environment such as in the migrant hostel industrial complexes in South Africa where thousands of men could be infected in one night through unsafe sex relationship [5]. In the case of Nigeria, there have been more cases of HIV in the army than anywhere else. Hence, the States with the large soldier populations like Benue, Nassarawa and Plateau have the greater number of HIV/AIDS cases [5].

\section{Some of the Reasons for Rise in HIV Scourge in Nigeria}

1) Some Nigerian soldiers in the Nigerian Army have been known to contact and spread the disease while on international peace keeping assignments [5].

2) Some children carriers of the virus were born with HIV which they got from their mothers who had failed to report for ante-natal care of standard and well equipped hospitals and clinics.

3) Attitudes of Nigerian people to unprotected sex and rising number of youths joining homosexual groups [17] [18].

4) Men who patronize prostitutes and engage in unprotected sex also transmit the virus to their unsuspected spouses [8]

5) Poverty in Nigeria is rising with almost 100 million people living on less than $\$ 1.00$ a day [19]. And this desperation for survival made female prostitution to be on the increase.

6) Indecent dressing and moral decadence in all schools in Nigeria.

\section{Mode of HIV/AIDS Transmission among Youths in Nigeria}

According to findings, many youths in Nigeria begin sexual intercourse at early age. About 50\% of high school students have sexual intercourse while in school [20]. About 6\% was reported having sexual intercourse below age 14 years. And about 39\% of the students interviewed confessed not using condoms during sexual intercourse. The specific modes of HIV/AIDS transmission in Nigeria are:

1) All forms of sexual intercourse may results in the transmission and constitute the single most important HIV epidemic in Nigeria.

2) Exposure to blood mainly through transfusion and needles sharing among the youths. This is the second most common route to HIV transmission.

3) Blood donors.

4) Rape among the underage girls by HIV carriers.

5) The pregnancy or substantial vertical (mother to child) transmission in Nigeria [21] [24].

\section{Reports of Sexual Immorality and Promiscuity in Nigeria Society}

There are several reports and documentations of sexual immorality and other forms of promiscuity in Nigeria society. Some of these are:

1) Video of women caught having sex in the bush with baby on her back in Imo State: Reported by: Arua Egwu on May 29, 2013. Accessed on the internet at 10:36 am. 
2) Student leaks video of her and her lecturer having sex. Posted by Tolu on the internet on June 19, 2013.

3) List of Nigerian Pastors who rape church members:

a) The story of "Men of God in Nigeria Bishop ChibuikeNwabneze, chairman of the communion of Bishop in Rivers states confessed to raping 15 years old girl. See http://www.vanguardngr.com/2013/07/rape.

b) Redeemed Christian Church of God, RCCG pastor nabbed over allege rape of 12 years old house maid. See the http://www.vanguardngr.com/2013/02/past.

c) Pastor 42 years charged with raping 12-years old girl. see http://www.premiumtimesng.com/regional/1155.

d) Pastor Emmanuel Mathew 50 docked for allegedly raping three primary school pupils in Abuja see http://www.premiumtimesng.com/metro/132040.

e) Deeper Life Bible Church Pastor, Eze Fidelis, confessed to defiling small girls see: http://www.vanguardngr.com/2013/07/why.

f) General Overseer of Mountain Movers Fire Ministries International Abuja: Pastor Prince Will accused of raping 14 year old, granted bail see: http://www.premiumtimesng.com/news/100138-r.

g) Police parade gay Pastor, Philips Ogbeborfor, alleged rape of member see: http://www.vanguardngr.com/2013/07/police.

h) Christ Apostolic Church Pastor, Ilesanmi Emmanuel, remanded pastor for alleged rape of church member see: http://www.premiumtimesng.com/regional/1259.

i) Pastor Atunde of Light of Hope Orphanage in Ogun State accused of raping minors of orphanage see: http://www.punchng.com./news/.

j) Boy 14 rapes nine-year old girl to death. By EniolaAkinkuotu, Punch Newspaper October 30, 2013 (accessed on the internet on Nov. 25, 2013).

k) OlalekanLasisi, 32 year Police Corporal attached to Ekiti State Police Command rapes and impregnated JSS 1 virgin (12 year old) girl. See: standard Newspaper, Monday Nov. 25, 2013.

m) 30year old security guard, EmekaNwabunwane lure 18 year old student to a classroom in the school and raped her. See PM News, July 23, 2013.

l) A 15-year-old Junior Secondary School student of Educational Legacy College, Ibadan has been raped by IsiakaSalimonu 43, who teaches Arabic because she had poor grades. See: Daily Time NG, March 4, 2012 written by Jewel Stephen.

n) Chairman of All Bishop in Rivers State, Bishop ChibuikeNwabneze was arrested for allegedly raping a 15 year old girl. Nigerian Bishop Rapes Female Student See: brimtime.com Wednesday, July 3, 2013 http://www.brimetime.com/2013/07/nigeria-bishop-rapes-female-student.

o) Prophet caught on top a married woman having sex. Thursday 31, October 2013. See http://www.brimtime.com/2013/10/prohet-caught-on-top-married-women.

p) 54 pregnant girls discovered in Lagos public school. May 29, 2013.Source: The Nigeria Today, May 29, 2013.

q) Pastor and Choir mistress caught having sex inside church. By Naijaurban. Posted on the net on 23rd March 2012 See: http://www.naijarurban.com/pastor-choir-mistress-caught-sex-church.

Source: [21].

\section{Marketing Concept and HIV/AIDS Business}

The Marketing concept is said to be the idea that social and economic justification for an organization's existence is the satisfaction of customer wants and needs while meeting organizational objectives.

Marketing has two facets. First, it is a philosophy, an attitude, a perspective, or a management orientation that stresses customer satisfaction. Second, marketing is a set of activities used to implement this philosophy [22]. Phillip Kotler [22] defines marketing as the human activities directed to satisfy human needs and wants through exchange process. Marketing is made up of four activities or functions:

1) Product Activities-these are concern with developing the "right" product for the consumers the marketer is attempting to serve.

2) Pricing Activities-involves determining the amount of money that will be charge for goods and services.

3) Promotion Activities-refer to those attempts by the marketer to communicate with consumers. It includes advertising, personal selling, sales promotion, publicity, and public relations.

4) Place Activities—make the product available when and where consumers want it. 
The American Marketing Association also defines Marketing as the process of planning and executing the conception, pricing, promotion, and distribution of ideas, goods, and services to create exchanges that satisfy individual and organizational goals [23].

Since exchange is the key term in the definition of marketing [22], every organization then strive to create something of value that people will be ready to receive(need/want), something of value in exchange of giving up something of money). It is believed that many organizations adopt production orientation strategy in order to survive in this competitive global marketing. A production orientation is a philosophy that focuses on the internal capabilities of the firm rather than on the desires and needs of the marketplace. According to Lam, et al., [22], production orientation asks these questions; what can we do best, what can our engineers design? What is easy to produce? etc. In this orientation, the management believes that if they build or produce it, consumers will come to buy it. This is known as Field of Dreams Orientation. With this field dreams orientation strategy some people in Nigeria including those expose to blood mainly through transfusion and needles sharing [24] are of the view that some pharmaceutical companies introduce HIV into the system in order to market and sell HIV/AIDS related products globally.

\section{Methodology}

The study utilized field survey to collect primary data. The population consists of sexually active men and women in Colleges, Polytechnic and Universities in Southwest, Eastern and Northern Nigeria. The sample consists of total 2500 students made up of 500 undergraduates' students each from East, West and Northern part of Nigeria and 1000 secondary school girls across the nation. The Universities and Polytechnics used for the study are: Lagos State University, Yaba College of Technology, LadokeAkintola University and Obafemi Awolowo University, in the western Nigeria. Delta State University and Federal Polytechnic, Nekede, were used for the study in the East. While in the North, Kano State Polytechnic and University of Abuja were used to conduct the study.

Descriptive, Cross-sectional study was used in the study to measure knowledge of the causes and prevention of HIV/AIDS; prevalence of abstinence behaviour and factors influencing abstinence behaviour among youths in Nigeria. The study was conducted in Lagos, Oyo, Delta, Kano and Federal Capital Territory. The study area of population made of Colleges, Universities and Polytechnics in these states.

The data was collected using both quantitative and qualitative data collection instruments. Both instruments had been field tested to ensure their reliability and validity. The usual age range of students enrolled in Nigeria Polytechnic and University is between 20 - 24 years and 24 - 29 years in some cases. Some students are younger or older than this age bracket. For this study, students who are not within the age range of 16 and 19 years were not eligible and did not participate in the study. Other eligibility criteria considered were consent of their parents or wards and respondents to participate in the study. The selected 2,500 students across the nation later completed a set of semi-structured questionnaire and interviewed that assessed among others, their demographic characteristics, sexual activity, self efficacy to refuse sex, social life styles, family background, attitude towards abstinence, knowledge of HIV/AIDS, self esteem, parental control, peer pressure for premarital sex, among others.

\section{Design}

For the purpose of this study a survey research design was used. And because majority of Nigerian girls and women are too reluctant to discuss about Sex or sex related issues, the following technique was adopted to collect data:

1) Oral interview data and information-70\%.

2) Observation of Sex behaviors and attitudes-20\%.

3) Questionnaire-10\%.

Out of the total population of 2500 students, only 50 students were administered questionnaire. Others prefer to be given oral interview as majority was afraid of anything to be documented about their sex lives. For this reason 10 students were selected from five (5) faculties (Management Sciences, Social Sciences, Art, Law and Science) of the Lagos State University for this exercise.

\section{Sampling Technique}

A quota random sampling techniques was adopted for this study. The fifty questionnaires were divided into five 
(5) faculties (i.e. 10 questionnaire per faculty) to gather the necessary information.

The 5-point Likert scale was adopted for this study ranging from strongly agrees, agree, undecided, disagree to strongly disagree. The questionnaire was made up of sections (i.e. A and B). Section A was used to collect bio data of the respondents and section $\mathrm{B}$ comprises of questions relating to the subject matter.

\section{Test of Hypotheses}

\section{HYPOTHESIS 1 TESTED USING QUESTION 10: I will feel embarrassed if my girl/boy friend or fiancée} ask me to go for HIV test (Table 2 \& Table 3).

\section{Decision}

The calculated value is (28.008) while the tabulated value is (1.96). This implies that the null $\left(\mathrm{h}_{0}\right)$ should be rejected. This means that Nigerian students have negative perception towards knowing their h HIV status.

\section{Hypothesis 2: Tested Using Question 14: NACA Has Been Able to Make Significant Impact on Control of HIV/AIDS Test (Table 4 \& Table 5)}

\section{Decision}

The null hypothesis should be rejected because the calculated value (12.898) is greater than tabulated value (1.96). This implies that NACA's campaign towards control of HIV in Nigeria is effective.

Table 2. One-sample statistics.

\begin{tabular}{ccccc} 
& N & Mean & Std. Deviation & Std. Error Mean \\
\hline QUESTION10 & 50 & 4.1000 & 1.03510 & 0.14639 \\
\hline
\end{tabular}

Research Study, 2014.

Table 3. One-sample test.

\begin{tabular}{|c|c|c|c|c|c|c|}
\hline & \multicolumn{6}{|c|}{ Test Value $=0.05$} \\
\hline & \multirow{2}{*}{$\mathrm{T}$} & \multirow{2}{*}{$\mathrm{df}$} & \multirow{2}{*}{ Sig. (2-tailed) } & \multirow{2}{*}{ Mean Difference } & \multicolumn{2}{|c|}{ 95\% Confidence Interval of the Difference } \\
\hline & & & & & Lower & Upper \\
\hline QUESTION10 & 28.008 & 49 & 0.000 & 4.10000 & 3.8058 & 4.3942 \\
\hline
\end{tabular}

Research Study, 2014.

Table 4. One-sample statistics.

\begin{tabular}{ccccc}
\hline & N & Mean & Std. Deviation & Std. Error Mean \\
\hline QUESTION14 & 50 & 2.2200 & 1.21706 & 0.17212 \\
\hline
\end{tabular}

Source: Research Study, 2014.

Table 5. One-sample test.

\begin{tabular}{|c|c|c|c|c|c|c|}
\hline & \multicolumn{6}{|c|}{ Test Value $=0.05$} \\
\hline & \multirow{2}{*}{$\mathrm{T}$} & \multirow{2}{*}{ df } & \multirow{2}{*}{ Sig. (2-tailed) } & \multirow{2}{*}{ Mean Difference } & \multicolumn{2}{|c|}{ 95\% Confidence Interval of the Difference } \\
\hline & & & & & Lower & Upper \\
\hline QUESTION14 & 12.898 & 49 & 0.000 & 2.22000 & 1.8741 & 2.5659 \\
\hline
\end{tabular}

Source: Research Study, 2014. 


\section{Hypothesis 3 Tested Using Question 19: Sex Education Can Help Students to Create the Right Attitude towards Sex in Nigeria (Table 6 \& Table 7)}

\section{Decision}

The null hypothesis should be rejected because the calculated value (32.301) is greater than tabulated value (1.96). This implies that sexuality education can help create objective attitude towards sexual intercourse among students.

\section{Hypothesis 4 Tested Using Question 23: By Organizing Behavioral Change Programs, Social Stigma Association with Those Living with HIV/AIDS Can Be Reduced (Table 8 \& Table 9)}

\section{Decision}

The null hypothesis should be rejected because the calculated value (54.899) is greater than tabulated value (1.96). This implies that behavioural change program can help change people's negative attitude towards people living with HIV/AIDS.

\section{General Results}

There are more females in Universities, Polytechnics and Colleges in Nigeria than males as reflected in the sample as $56.5 \%$ of the respondents are female while $43.5 \%$ are males. Majority of the respondents are below the age of 25 years and only $1.2 \%$ are above 29 years. The age group $20-24$ years is $18.6 \%$ of the respondents.

Knowledge/Awareness of condom use: $94.6 \%$ of the respondents know about condoms. 58.4\% of the respondents are aware of male and female condoms while $2.2 \%$ of the respondents are aware of female condoms and $5.4 \%$ of the respondents are not aware of female condoms. Distribution of respondents according to source of respondents' knowledge of condoms is as follow: electronic media, 69.93\%; print media, 19.7\%; peer information and word of mouths, $18.34 \%$; partners, $7.33 \%$.

$81.6 \%$ of the respondents gave reasons for their use of condoms while $18.4 \%$ did not respond. The reasons for using condoms by respondents are given below:

- $69.3 \%$ use condom against STI \& HIV/AIDS.

- $30.7 \%$ use condom against pregnancy.

Those who are not using condoms cited various reasons such as:

- Cultural inappropriateness, $98.4 \%$ of the respondents.

- Partners wish and request, $84.1 \%$ of the respondents.

- Concern about condoms effectiveness, 31.7\% of respondents.

- Reduction of sexual pleasure, $15.9 \%$ of the respondents.

Table 6. One-sample statistics.

\begin{tabular}{ccccc} 
& N & Mean & Std. Deviation & Std. Error Mean \\
\hline QUESTION19 & 50 & 4.2600 & 0.92162 & 0.13034 \\
\hline
\end{tabular}

Source: Research Study, 2014.

Table 7. One-sample test.

\begin{tabular}{|c|c|c|c|c|c|c|}
\hline & \multicolumn{6}{|c|}{ Test Value $=0.05$} \\
\hline & \multirow{2}{*}{$\mathrm{T}$} & \multirow{2}{*}{ Df } & \multirow{2}{*}{ Sig. (2-tailed) } & \multirow{2}{*}{ Mean Difference } & \multicolumn{2}{|c|}{ 95\% Confidence Interval of the Difference } \\
\hline & & & & & Lower & Upper \\
\hline QUESTION19 & 32.301 & 49 & 0.000 & 4.21000 & 3.9481 & 4.4719 \\
\hline
\end{tabular}

Source: Research Study, 2014. 
Table 8. One-sample statistics.

\begin{tabular}{ccccc}
\hline & N & Mean & Std. Deviation & Std. Error Mean \\
\hline QUESTION23 & 50 & 4.2000 & 0.53452 & 0.07559 \\
\hline
\end{tabular}

Source: Research Study, 2014.

Table 9. One-sample test.

\begin{tabular}{|c|c|c|c|c|c|c|}
\hline & \multicolumn{6}{|c|}{ Test Value $=0.05$} \\
\hline & \multirow{2}{*}{$\mathrm{T}$} & \multirow{2}{*}{ Df } & \multirow{2}{*}{ Sig. (2-tailed) } & \multirow{2}{*}{ Mean Difference } & \multicolumn{2}{|c|}{ 95\% Confidence Interval of the Difference } \\
\hline & & & & & Lower & Upper \\
\hline QUESTION23 & 54.899 & 49 & 0.000 & 4.15000 & 3.9981 & 4.3019 \\
\hline
\end{tabular}

Source: Research Study, 2014.

The study decided that the mean knowledge level was high $88.2 \%$ however; there are many misconceptions about the transmission routes. 3.4\% of the total students believe that HIV/AIDS may be transmitted through mosquito bites.36.7\% ignored that oral intercourse circles risk of transmitting HIV/AIDS. And only 30.9\% of the students use condoms once in a while.

\section{Conclusion}

Information on HIV/AIDS and sexual behaviours and practice among youths in Nigeria is still inadequate. The study discovered among others that HIV/AIDS phenomenon by youths in Nigeria is ill-informed. Some of the youths in the country see HIV/AIDS development propaganda to help multinational pharmaceutical companies sell their condoms and other sex related products. A significant number of the youths in Nigeria do not really believe that HIV/AIDS really exists. Also, some of the youths do not bother about any form of precaution or prevention during sexual intercourse. Many of the youths believe that abstinence could be a better solution to prevent HIV/AIDS but not everybody can abstain and stick to one partner.

\section{Recommendation}

Appropriate information, education and communication strategies need to be developed and packaged toward re-orientation of youths' view, perception and understanding of HIV/AIDS in Nigeria.

\section{Some of the Interview Questions Administered}

1) Do you use condoms during sexual intercourse?

2) How often do you use condom during sexual intercourse?

3) Do you encourage your partner to use condoms?

4) What are the reasons for not using condoms?

\section{Acknowledgements}

Contributions of the final year 2013 students of Marketing and Business Administration Departments of Faculty of Management Sciences of the Lagos State University in the areas of interview, data collection, writing assistance, administering questionnaires, etc. in the course of this research were deeply noted.

\section{References}

[1] Shaffer's, S. (1994) The Impact of HIV/AIDS on Education: A Review of Literature \& Experience. UNESCO, Paris.

[2] Strong, B., Devault, C., Sayad, B.W. and Yarber, W.L. (2005) Human Sexuality Diversity in Contemporary America. McGraw-Hill, New York

[3] WHO (2008) Reports on the Global AIDS Epidemic. Joint United Nations Program on HIV/AIDS (UNAIDS) and World Health Organization, Geneva. 
[4] UNAIDS (1999) 1999 World AIDS Campaign with Children and Young People. Fact and Figure, Geneva.

[5] Abunkun, A. (2013) Highest HIV/AIDS Infected State in Nigeria, Benue Top the List. Hotnaijanews Accessed on the Internet on 24/11/2013.

[6] Nigeria Watch Accessed on the Internet on 16/3/2013.

[7] Ekweremadu, B. (2014) 8 Out of 10 Nigerian Men Don’t Use Condoms. Nigerian Monitor, Tuesday 14, January, 2014. Accessed on the Internet on 14/10/2014.

[8] Wende, G. (2003) Basic Facts on HIV/AIDs. Mrs. Wende, Executive Secretary of the Benue State Action on Control of AIDs. www.nigeriawatch.com/news/1444

[9] Ogundana, F. (2002) Attitude to Death: An Obstacle to Sexual Behavior Change in Urban Ekiti. Nigeria Journal of Counseling and Applied Psychology, 1, 56-57.

[10] Odu and Akande (2007) Motivations for Extramarital Sex in Exclusive Marriage among Nigerians. The Nigerian Journal of Social Health, 1, 1.

[11] Davis, K.R. and Welter, S.C. (1999) The Effectiveness of Condom in Reducing Heterosexual Transmission of HIV. Family Planning Perspective, 31, 272-279. http://dx.doi.org/10.2307/2991537

[12] Nigeria Camera (2013) Three Nigerian University Students Pose Nude in Hostel.

[13] Daily Sun Newspaper. Accessed on Net on 3/12/2013.

Gbola, S. (2012) Poverty in Nigeria and Female Prostitutes. Saturday Tribune, 20 October 2012.

[14] Independent Newspaper (2014) Benue, a Big HIV/AIDS Worry for Nigeria. Accessed on the Net on 24/11/2013 @8.15 am.

Research Survey (2013) Egun Tribe View of HIV/AIDS and Contraception.

[15] UNAIDS (2005) Report on The Global HIV/AIDS Epidemic. UNAIDS, December 2005. UNFPA (2005) The Promise of Equity: Gender Equity, Reproductive Health and Millennium Development. United Nations Population Fund Technical Report, State of World Population, 2005.

[16] Aneki.com (2013) Countries with the Highest Level of HIV Infection.

[17] Akanle, F.F. (2007) Condom Use as Preventive Measure against HIV/AIDS among Nigerian Unmarried Youths. Ife Journal of Theory and Research in Education, 10, No. 1.

[18] Akanle, F.F. (2005) Sexual Behavior and Perception of HIV/AIDS among Nigerian Youths in South West Nigeria. An Unpublished PhD Thesis in the Faculty of Education, University of Ado, Ekiti.

[19] Tribune Newspaper Report (2012).

[20] Nigeria Today (2013).

[21] Adeche, Fran Posted on the Net and Accessed on the Internet on September 10, 2013 @12.02 pm.

[22] Lamb Jr., C., Hair Jr., J.F. and McDaniel, C. (2000) Marketing. 5th Edition, South-Western College Publishing, Cincinnati.

Awoniyi, M.A. (2010) Marketing_-Principles, Management and Strategies. De-Mac Press, Nigeria, 29.

[23] Bennett, P.D. (1995) Dictionary of Marketing Terms. 2nd Edition, American Marketing Association, Chicago, 115.

[24] Omorepie, G. (2003) Risk Perception of HIV/AIDS among Youths in Nigeria. Contribution to Regional and Global Meeting on HIV/AIDS, Compiled by Nigerian Institute of Medical Research and National Action on AIDS (NACA). 


\section{Appendices}

\section{QUESTIONNAIRE}

\section{SECTION A (DEMOGRAPHIC DATA)}

\section{QUESTIONNAIRE}

\section{INSTRUCTIONS}

Please tick $(\sqrt{ })$ as appropriate each of the following questions information provided will be kept strictly confidential.

\section{SEX}
(a) Male
( )
(b) Female ( )

2. AGE GROUP
(a) 16-19 ( )
(c) 24 - 27 years ( )
(b) 20 - 23 years
( )
(d) 28 and above ( )

3. MARITAL STATUS

(a) Single (
(c) Widow ( )
4. FACULTIES

(a) Science ( )

(b) Married ( )

(d) Divorced ( )

(e) Others ( )

(e) Law ( )

(b) Mgt Sciences ( )

(c) Soc. Sciences

(d) Art ( )

5. RELIGION

$\begin{array}{lll}\text { (a) Islam ( ) } & \text { (b) Christianity ( } \quad \text { ) } & \text { (c) Traditional ( ) }\end{array}$

6. Have you ever gone for HIV/AIDS test? Yes ( ) No ( ) 


\section{SECTION B}

Note: NACA means National Agency for the Control of AIDS.

There are 20 questions on this section please tick ( ) from Strongly Agree (SA), Agree (A), Undecided (U), Disagree (D) and Strongly Disagree (SD).

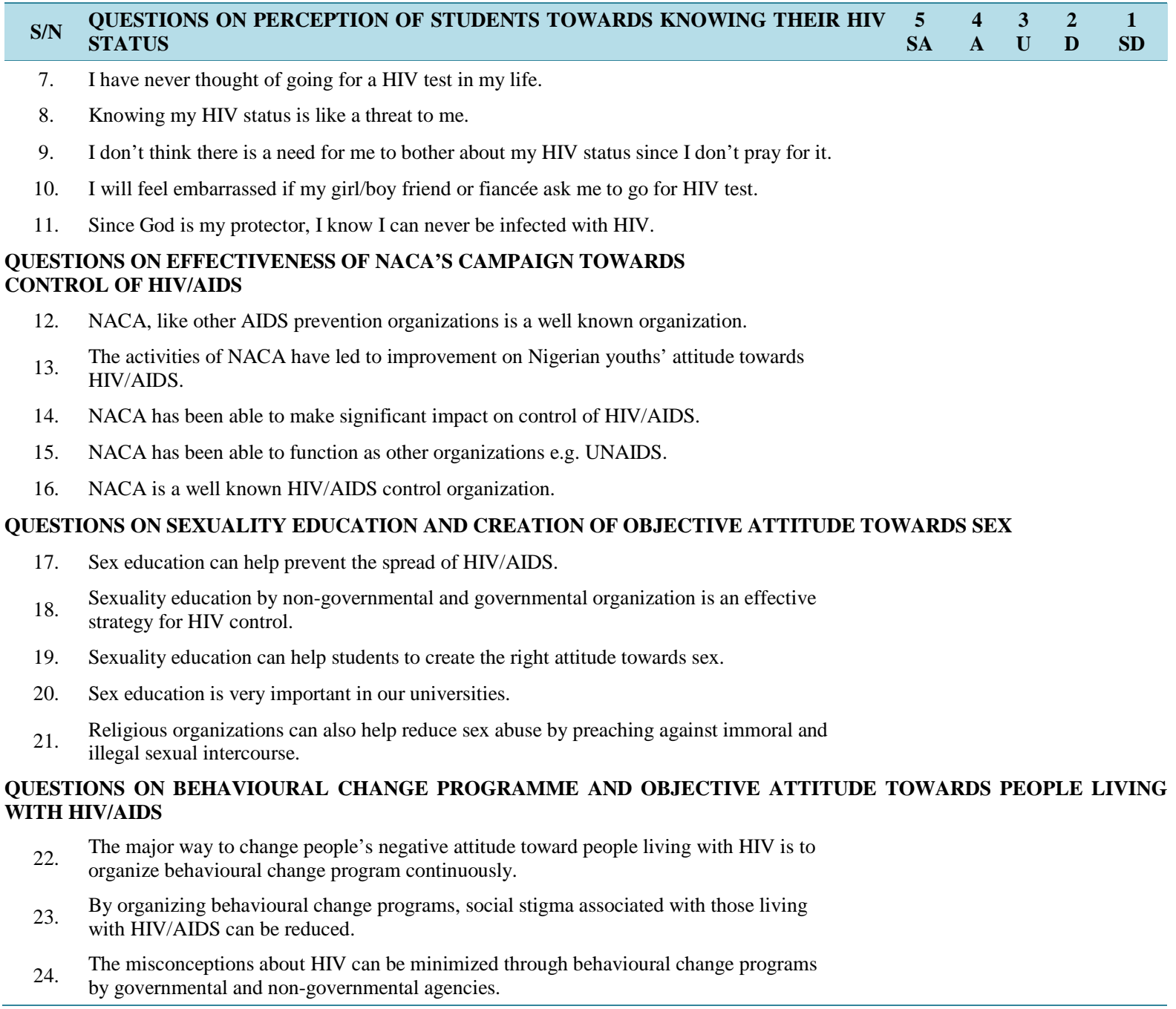

Source: Research Study, 2014. 